\title{
EPIDEMIOLOGICAL PROFILE OF LEPROSY CASES ATTENDING TERTIARY CARE HOSPITAL IN VISAKHAPATNAM
}

G. Ajay Kumar ${ }^{1}$, M. Sailaja Rani ${ }^{2}$, I Sree Gowthami ${ }^{3}$, B. Balachandrudu'4, S. Dhanyasree ${ }^{5}$, K. Hanusha ${ }^{6}$, S. S. Amrutha Bindu ${ }^{7}$,

S. N. R. Chakravarthy ${ }^{8}$

${ }^{1}$ Assistant Professor, Department of Dermatology Venereology and Leprology, King George Hospital, Andhra Medical College, Andhra Pradesh, India.

${ }^{2}$ Assistant Professor, Department of Dermatology Venereology and Leprology, King George Hospital, Andhra Medical College, Andhra Pradesh, India.

${ }^{3}$ Postgraduate Student, Department of Dermatology Venereology and Leprology, King George Hospital, Andhra Medical College, Andhra Pradesh, India.

${ }^{4}$ HOD, Department of Dermatology Venereology and Leprology, King George Hospital, Andhra Medical College, Andhra Pradesh, India. ${ }_{5}^{5}$ Assistant Professor, Department of Dermatology Venereology and Leprology, King George Hospital, Andhra Medical College, Andhra Pradesh, India.

${ }^{6}$ Postgraduate Student, Department of Dermatology Venereology and Leprology, King George Hospital, Andhra Medical College, Andhra Pradesh, India.

${ }^{7}$ Postgraduate Student, Department of Dermatology Venereology and Leprology, King George Hospital, Andhra Medical College, Andhra Pradesh, India.

${ }^{8}$ Postgraduate Student, Department of Dermatology Venereology and Leprology, King George Hospital, Andhra Medical College, Andhra Pradesh, India.

\begin{tabular}{l}
\hline ABSTRACT \\
BACKGROUND \\
This study was undertaken to determine the epidemiology of leprosy patients attending King George Hospital, between 2016 and
\end{tabular}
2018.

\section{MATERIALS AND METHODS}

Every consecutive patient suspected of having leprosy was included in the study. All the patients attending dermatology Out Patient Department and cases referred from other departments were included in the study during the 2 years study period.

Total number of patients included in the study-315, Number of males- 213, Number of females-102. All patients suspected to have leprosy were confirmed by clinical examination including sensory and motor examination, slit skin smear and biopsy. Confirmed cases were categorized into respective spectrum. The sample included all age groups. Only new cases were included in the study.

Statistical analysis used- Percentages and tabular forms are used in this study.

\section{RESULTS}

Most commonly involved are males and between the age group of 25-45. The overall prevalence of leprosy attending King George Hospital, Visakhapatnam, between the years 2016 and 2018 is 2.5; prevalence among male patients is 1.71; prevalence among female patients is 0.8 . The prevalence previously in $2016-2017$ as given by the district leprosy prevention office is 0.27 . The most common spectrum is of borderline tuberculoid type.

\section{CONCLUSION}

The prevalence of leprosy is still continuing to be high and this may be due to the high prevalence in areas in and around Visakhapatnam, Srikakulam and Orissa as most of the patients attending our OPD are from these areas. Endemicity of the disease, poor knowledge of the patients about disease, leads to no treatment or irregular treatment and exposure to close contacts which in turn lead to spread of infection to the susceptible hosts.

\section{KEY WORDS}

Epidemiology of Leprosy.

HOW TO CITE THIS ARTICLE: Kumar GA, Rani MS, Gowthami IS, et al. Epidemiology profile of leprosy cases attending tertiary care hospital in Visakhapatnam. J. Evolution Med. Dent. Sci. 2019;8(08):527-531, D0I: 10.14260/jemds/2019/116

\section{BACKGROUND}

Epidemiological study of leprosy is an important public health tool to monitor its progress on account of new transmission taking place in an area. This also helps to

'Financial or Other Competing Interest': None.

Submission 28-09-2018, Peer Review 09-02-2019,

Acceptance 16-02-2019, Published 25-02-2019.

Corresponding Author:

Dr. S. Dhanyasree,

Andhra Medical College,

Visakhapatnam, Andhra Pradesh,India.

E-mail:isreegowthami24@gmailcom

DOI: $10.14260 /$ jemds/2019/116

\section{(c) $(1)(9)$}

understand the trend of disease and causes of transmission. Prevalence of leprosy suggests ongoing transmission. ${ }^{[1]}$ It also helps to understand the trend of the disease. The prevalence of leprosy suggests the levels of ongoing transmission in various groups and subgroups. ${ }^{[2]}$

The measurement of prevalence of disease is thus important for planning to interrupt ongoing transmission, if any, in the community:[1]

Several attempts have been made to estimate the prevalence of leprosy in the states of Tamil Nadu. ${ }^{[2],[3],[4],[5],[6]}$ Uttar Pradesh ${ }^{[4],[6]}$ Maharashtra[7] and elsewhere. 


\section{Objectives}

1. To know the epidemiology of leprosy.

2. To know the Prevalence of leprosy in patients attending tertiary care hospital.

\section{MATERIALS AND METHODS}

Study Design

Descriptive study.

\section{Study Setting}

Tertiary care hospital in Visakhapatnam.

\section{Study Population}

All suspected cases of leprosy attending the dermatology OP.

\section{Sample Size}

All suspected cases of leprosy attending the Dermatology OP and cases referred from other Departments between January 2016-2018 are included in the study. Sample size obtained was $=315$

\section{Inclusion Criteria}

All new clinically diagnosed cases of leprosy which are confirmed by slit skin smears and biopsy.

\section{Exclusion Criteria}

1. Diagnosed cases of leprosy before the study period.

2. Study subjects not willing to participate.

\section{Study Procedure}

In all suspected cases of leprosy complete clinical examination including sensory and motor examination, examination of peripheral nerves, slit skin smear for acid fast bacilli and biopsy, and were done. Confirmed cases were categorized into TT, BT, BB, BL, LL and Neuritic type based on clinical examination and biopsy. Slit skin smear was taken from ear lobules, sites of lesion and over the dorsum of fingers. Then smears are stained with Ziehl Nelson (ZN) staining for the demonstration of acid-fast bacilli. Bacteriological and morphological indices were calculated based on smear findings.

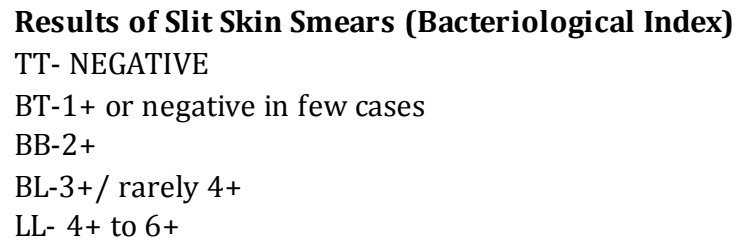

\section{Biopsy Findings}

\section{Tuberculoid Leprosy (TT)}

Atrophy and flattening of epidermis, presence of tuberculoid granulomas in the dermis and lower layers of epidermis.

\section{Borderline Tuberculoid (BT)}

Presence of epithelioid cell granulomas containing Langhans giant cells and is surrounded by moderate mantle of lymphocytes, in the dermis. Grenz zone is seen

\section{Mid Borderline (BB)}

There is presence of both epithelioid cells and macrophagescontaining few bacilli, with few lymphocytes in the dermis. Intracellular and extracellular oedema in the granulomas and dermis is seen.

\section{Borderline Lepromatous (BL)}

Dermis showing presence of granulomas containing lymphocytes, histiocytes, foamy macrophages containing bacilli, there is presence of grenz zone.

\section{Lepromatous Leprosy (LL)}

Granulomas containing foamy macrophages containing multiple bacilli, lymphocytes are few in number and are scattered diffusely among the macrophages.

\section{Grenz Zone is Present}

- Total size of the sample is 315 (Males-213, Females102).

- Most of the age groups are between 20-45 years.

\section{Defining Prevalence of Leprosy-}

A new, active, confirmed and untreated leprosy case detected among an surveyed population who is known to be leprosy free is defined as an incident case, ${ }^{[1]}$ prevalence was calculated using the formula-

Total no. of leprosy cases between 2016-2018 x 100

Total no. of patients attending between 2016-2018

\section{Statistical Analysis}

Data is entered in Microsoft excel spread sheet and analysis was done with excel and categorical data is represented.

\section{RESULTS}

- The overall prevalence of leprosy in King George hospital, Visakhapatnam is 2.5,

- $\quad$ The rate of prevalence in males is 1.71

- $\quad$ Rate of prevalence in females is 0.82

- Most commonly males are involved compared to females, according to the prevalence rates.

- $\quad$ Most commonly involved age groups are between 20-45 years.

- Most common spectrum is Borderline Tuberculoid(66.2\%) followed by Borderline Lepromatous- 10.4\%, Pure Neuritic Hansen's- 8.5\%, Lepromatous Leprosy$6.9 \%$

- Tuberculoid pole and mid borderline spectrum- 0.3\%.

- According to the age group and gender the results are postulated in the tabular forms in the end.

\begin{tabular}{|c|c|c|c|c|c|c|c|}
\hline & TT & BT & BB & BL & LL & $\begin{array}{c}\text { Pure } \\
\text { Neuritic }\end{array}$ & Total \\
\hline Males & 1 & 160 & 1 & 19 & 14 & 18 & 213 \\
\hline Females & 0 & 72 & 0 & 14 & 8 & 8 & 102 \\
\hline \multicolumn{7}{|c|}{ Table 1 } \\
\hline
\end{tabular}




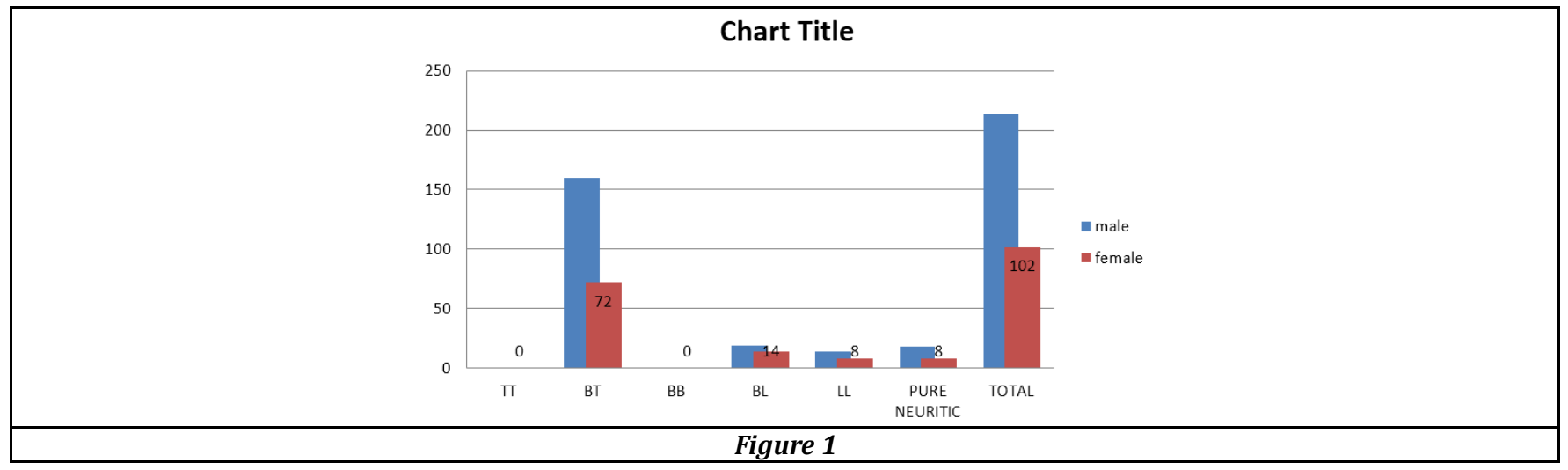

\begin{tabular}{|c|c|c|c|c|c|c|c|c|c|c|c|c|}
\hline & TT & TT & BT & BT & BB & BB & BL & BL & LL & LL & $\begin{array}{c}\text { Pure } \\
\text { Neuritic }\end{array}$ & $\begin{array}{c}\text { Pure } \\
\text { Neuritic }\end{array}$ \\
\hline & Male & Female & Male & Female & Male & Female & Male & Female & Male & Female & Male & Female \\
\hline $\begin{array}{l}\text { Age } \\
\text { Group }\end{array}$ & & & & & & & & & & & & \\
\hline $\begin{array}{c}1-10 \\
\text { Years }\end{array}$ & & & 2 & 2 & & & & & & & & \\
\hline $\begin{array}{l}11-20 \\
\text { Years }\end{array}$ & 1 & & 6 & 3 & & & 1 & & & & & \\
\hline $\begin{array}{l}21-30 \\
\text { Years }\end{array}$ & & & 30 & 17 & 1 & & 4 & 3 & 5 & 1 & 1 & 1 \\
\hline $\begin{array}{l}31-50 \\
\text { Years }\end{array}$ & & & 80 & 29 & & & 44 & 7 & 9 & 5 & 10 & 6 \\
\hline $\begin{array}{l}51-70 \\
\text { Years }\end{array}$ & & & 18 & 5 & & & 2 & 2 & 3 & 2 & 7 & 1 \\
\hline $\begin{array}{c}71-100 \\
\text { Years }\end{array}$ & & & 2 & & & & & & & 1 & & \\
\hline
\end{tabular}

\section{Percentage of Individual Spectrums}

- Borderline Tuberculoid- $66.2 \%$

- Borderline Lepromatous- $10.4 \%$

- Pure Neuritic Hansen's- $8.5 \%$

- Lepromatous Leprosy- $6.9 \%$

- Tuberculoid pole and mid borderline spectrum- $0.3 \%$

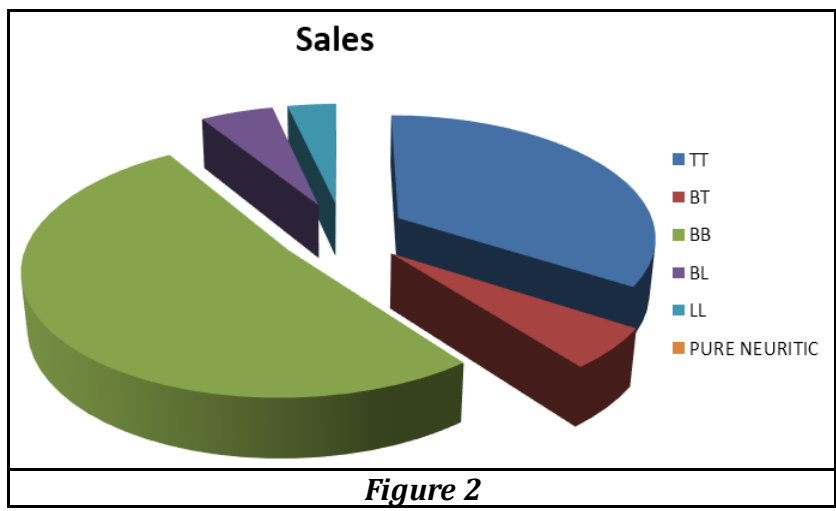

\section{DISCUSSION}

- Leprosy is a chronic granulomatous disorder caused by mycobacterium leprae. It is a spectral disease in which clinical and pathological features reflect cell mediated immunity of the host. Primarily involves the skin and peripheral nerves, also involves other tissues.

- Most common presentation is hypo/ hyper pigmented/erythematous macules or plaques,

- The disease may spread by close contact among families[8], nasal droplets.

\section{Classification}

- $\quad$ Ridley- Jopling classification- based on the cell mediated immunity of the host.

- Tuberculoid leprosy.

- Borderline tuberculoid.

- Mid borderline leprosy.

- Borderline lepromatous

- Lepromatous leprosy.

\section{Indian Classification}

- Lepromatous.

- Tuberculoid.

- Indeterminate.

- Borderline.

- Maculo anaesthetic.

- Polyneuritic.

\section{WHO Classification}

- Paucibacillary-1-5 skin lesions.

- No nerve involvement or only one nerve with ir without skin lesions.

- Skin smears negative at all sites.

- Multibacillary- 6 or more skin lesions.

- Involvement of more than one nerve irrespective of skin lesions.

- $\quad$ Skin smears positive at any site.

Tuberculoid Hansen's

- Neural symptoms- pain, loss of sensations, tingling, muscle weakness/ paralysis 
- Cutaneous- single or few well defined, erythematous plaques with raised and clear-cut edges, surface - dry, hairless and usually scaly, with loss of sensations.

- Nerves- thickened, presence of feeding nerves, abscesses.

- $\quad$ Skin smears- usually negative.

- Lepromin test- strongly positive.

- Course- relatively benign and stable with good prognosis.

\section{Borderline Tuberculoid}

- Similar to TT but evidence if disease being not contained.

- Margins are not that well defined-borders may start sloping outwards.

- Number of lesions is usually 3-10, large hypopigmented asymmetrical patches, surface is dry and scaly, with diminished sensations.

- $\quad$ Presence of satellite lesions.

- Peripheral nerves- thickened, asymmetrical.

- $\quad$ Susceptible to type 1 reaction.

- If left untreated- continues for years with recurrent reactions leading to progressive nerve damage paralysis and finally deformities.

\section{Mid Borderline (BB)}

- Multiple skin lesions.

- Dimorphous type of skin lesions.

- The lesions are annular with the inner edge of the lesion well demarcated, punched out and outer edge ill-defined and slopes towards normal skin.

- $\quad$ The typical characteristic lesions of mid borderline are inverted saucer shaped appearance of the lesions

- $\quad$ Nerve damage may be variable.

- It is an unstable form.

- If it is formed by downgrading from borderline tuberculoid- there is multiple nerve enlargement, which are involved asymmetrically.

- It is due to upgrading from borderline lepromatousneurological deficit may not be present.

- Mostly downgrades to lepromatous pole if left untreated.

\section{Borderline Lepromatous}

- $\quad$ There is presence of numerous skin lesions

- $\quad$ The typical lesions of this spectrum are multiple slightly infiltrated macules, which are coppery to skin coloured, the may be round oval in shape edges may not be well defined and the distribution of lesions is not symmetrical.

- Progression of the disease produces papules, nodules, plaques with sloping margins.

- If there is presence of associated large lesions it indicates downgrading of the disease.

- $\quad$ Sensory impairment is minimal.

- Nerve involvement is widespread and less asymmetrical.

- $\quad$ Glove and stocking type if anaesthesia starts to develop but in not complete.

- More prone to develop type 2 reaction.

- $\quad$ Prognosis may be variable.

\section{Lepromatous Leprosy}

- Presents as multiple, small, shiny, coppery coloured macules' with slight infiltration, which are ill defined.

- The distribution of lesions is bilaterally symmetrical.

- Sensations are normal.

- The infiltrated lesions are of three distinct forms-

- Diffuse lepromatous leprosy-

- Skin has a shiny look with slight infiltration.

- It is best appreciated by pinching the skin between fingers.

- Thickness is more marked over the face, forehead, ear lobules, nose, malar prominences.

- $\quad$ Ear lobule thickening and nodulation is best appreciated by examining standing behind the patient.

- Infiltrated lepromatous leprosy-

- It is an advanced stage of macular type of lepromatous leprosy with easily visible infiltration.

- Nodular lepromatous leprosy-

- Result of progressive deterioration of the macular, diffuse or infiltrated forms of lepromatous leprosy.

- The nodules develop initially over the ears, later involves other sites like buttocks, extremities.

- The infiltrated plaques accentuate the skin folds over the face giving the appearance of leonine facies.

- There is presence of extensive peripheral anaesthesia

- Sensory loss is symmetrical, and it is first detected over the extensor aspect of forearms, legs, hands, feet producing the characteristic glove and stocking type of anaesthesia.[9]

- Weakness of intrinsic muscles of hands and feet occur.

- Eye changes- superciliary and ciliary madarosis, superficial punctate keratitis, iris pearls, iritis, iridocyclitis, secondary cataracts, glaucoma, cranial nerve palsies occur in the later stages.

- Nasal changes- nasal stuffiness, formation of crusts, anosmia, perforation of the nasal septum, destruction of the nasal cartilage leading to collapse

- Mouth, pharynx, Larynx-papules, nodules, perforation of palate may occur

- Involvement of vocal cords in the larynx produces fibrosis and make them immobile.

- Mucosa- there may be thickening, formation of nodules, and ulceration.

- Gynecomastia may develop.

- Bone changes may occur in the bones of hands feet and skull

- Distal phalanges- atrophy and resorption producing shortening

- Pencilling of the metatarsals and tarsal bones

- Skull- atrophy of anterior nasal spine and maxillary alveolar process producing the characteristic Facies leprosa/ Moller Christensen facies- which is an autopsy finding

- Testes- epididymo-orchitis may occur leading to atrophy of the testes

- Kidneys- there are many complications occurring like glomerulonephritis, interstitial nephritis, pyelonephritis, amyloidosis. 


\section{Special Forms of Leprosy}

Lucio Leprosy

- Also known as lepra boneta or beautiful leprosy.

- It is a rare form of lepromatous leprosy, mostly seen in Mexico.

- It is slowly progressive non-nodular diffuse infiltration of the skin, making the skin look waxy and shiny.

- There is loss of eyebrows and eyelashes.

- There will be oedema of hands and feet mimicking myxedema.

\section{Lazarine Leprosy}

- It is an unusual expression of TT/BT leprosy.

- There will be spontaneous ulceration over the skin lesions.

- Predisposing factors are- protein malnutrition, debilitating illness, immunosuppression.

- Histopathology shows necrosis due to extreme cellular hypersensitivity.

\section{Histoid Hansen's}

- Occurs as a consequence of dapsone monotherapy or due to inadequate therapy (Denovo)

- Presents as smooth, shiny, hemispherical, dome shaped, non-tender, soft to firm nodules.

- They may be superficial/ subcutaneous, / deeply fixed/ plaques which appear over normal looking skin.

- Mostly involving face, back of the trunk, buttocks, extremities and bony prominences.

- Histopathology shows predominance of spindle shaped cells and large number of acid fast bacilli.

\section{Autoaggresive Hanseniasis}

- It occurs mainly in lepromatous leprosy.

- The clinical and immunological features resemble autoimmune connective tissue disorders.

- Occurs due to stimulation of B lymphocytes by the antigenic complexes of the Mycobacterium leprae.

- Presents with features of prolonged fever, anorexia, weight loss, arthralgia, malar rash, erythema multiforme like or necrotizing vasculitis like skin lesions.

- There is presence of detectable antibodies in the serum.

\section{CONCLUSION}

The prevalence of leprosy continues to be high and this may be due to the high prevalence in the areas in and around Visakhapatnam, Srikakulam and Orissa as most of the patients attending our OPD are from these areas. Endemicity of the disease, poor knowledge of the patients about disease, leads to no treatment or irregular treatment and exposure to close contacts which in turn lead to spread of infection to the susceptible hosts.

\section{REFERENCES}

[1] Kumar A, Girdhar A, Chakma JK. Incidence of leprosy Firozabad District (Uttar Pradesh). Indian J Dermatol Venereol Leprol 2018;84(4):403-7.

[2] Rao PS, Karat AB, Kaliaperumal VG, et al. Transmission of leprosy within households. Int J lepr Other Mycobact Dis 1975;43(1):45-54.

[3] Jesudasan K, Bradley D, Smith PG, et al. Incidence rates of leprosy among household contacts of primary cases. Indian J Lepr 1984;56(3):600-14.

[4] Kumar A, Girdhar A, Girdhar BK. Incidence of leprosy in Agra district. Lepr Rev 2007;78(2):131-6.

[5] Jesudasan K, Bradley D, Smith PG, et al. Time trends in the analysis of incidence rate of leprosy among household contacts. Indian J Lepr 1984;56(4):792806.

[6] Sharma VK. The epidemiological significance of leprosy within the household. Int J Lepr Other Mycobact Dis 1968;36(1):1-16.

[7] Ganapati R, Revankar CR. Associated cases in the families of school children with leprosy. Ind J Lepr 2005;177(4):4.

[8] George R, Rao PS, Mathai R, et al. Intrafamilial transmission of leprosy in Vellore Town, India. Int J Lepr Other MYcobact Dis 1993;61(4):550-5.

[9] Declerq E. Reflections on the new WHO leprosy indicator: the rate of new cases with grade 2 disabilities per 1 lakh population per year. Lepr Rev 2011;82(1):3-5. 